\title{
Pathology of Spontaneous Pox Virus Infection of Sheep and Goat in Jammu Region
}

\author{
Sankalp Sharma $^{1 *}$, Nawab Nashiruddullah ${ }^{1}$ and Jafrin Ara Ahmed ${ }^{2}$
}

${ }^{1}$ Division of Veterinary Pathology, ${ }^{2}$ Division of Veterinary Physiology and Biochemistry, Faculty of Veterinary Sciences and Animal Husbandry, Sher-e-Kashmir University of Agricultural Science and Technology of Jammu, RS Pura, Jammu \& Kashmir- 181102, India

*Corresponding author

\begin{abstract}
A B S T R A C T
An investigation was carried out to study the pathology of spontaneous capripox virus infection amongst sheep and goat in Jammu region through clinical survey and confirmatory laboratory diagnosis. Clinically, the disease exhibited an acute febrile phase and a less severe but prolonged phase. Cutaneous lesions were visible during the febrile phase progressing through erythematous maculo-papular stages and formation of nodules. Healing was typified by ulceration and characteristic pock lesions over sparsely haired/wooled areas of the head and other body parts. Systemic lesions included circumscribed necrotic areas on the liver surface, circular grayish-white plaques in the mucosa of the abomasum along with mild catarrhal enteritis and white necrotic foci on the kidney. In the respiratory system, a consistent finding was the presence of multifocal pneumonia and grayish-white papules, nodules or plaques throughout the lung surface. Histopathologic alterations of skin were marked along with presence of eosinophilic intracytoplasmic inclusion bodies the spinous cells. Surface lesions of lung tissue were characterized by noticeable pleuritis and massive fibrosis. Bronchial hyperplasia and bronchiolar epithelium metaplasia into rounded cells was observed. Alveolar changes were marked by alveolitis and metaplasia of lining epithelium to type II pneumocytes. Intracytoplasmic eosinophilic inclusions could be seen in bronchiolar epithelium and other cells in the alveolar areas. Surface lesions on the liver corresponded with focal degeneration and necrosis of hepatocytes along with demonstrable eosinophilic intracytoplasmic inclusion bodies in biliary epithelium. Mucosal lesions in the abomasum were characterized by vacuolar endothelial degeneration and thrombosis of serosal blood vessels. Intestinal sections revealed atrophy of villi and inflammatory cells in the submucosa. Changes in the kidneys were typified by membrano-proliferative glomerulonephritis, while lymphoid depletion and cystic cavitation of follicles were noticed in the spleen and lymph nodes.
\end{abstract}

\section{Introduction}

Sheep and Goat pox is a highly contagious viral disease of sheep and goats and in sheep, it is considered to be economically the most important in the tanning sector due to its slow and permanent scar formation (Gitao et al., 2017). Sheep pox is also known as ovine pox or Laccavalle, caused by virus namely
Sheeppoxvirus (SPPV) (Buller et al., 2005), while the other related members of the genus include goat pox virus (GTPV) and lumpy skin disease virus (LSDV) (Van Regenmortel et al., 2000). The causative agents are considered to be very host-specific. Even then, cross-transmission of infection has been reported. However, occasionally some CaPV strains infect both sheep and goats. 
Instances were recorded when SPPV were found to affect goats in Makhdoom, India (Bhanuprakash et al., 2010) or when GTPV were found to affect both goats and sheep in Samba district of Jammu and Kashmir, India (Ramakrishnan et al., 2016). In view of the limited documentation of sheep and goat pox disease in animals of Jammu region, it was felt necessary to conduct a blanket screening of the small ruminant populations in areas where they are largely reared. The present study therefore was proposed to study the pathology of circulating Capripoxvirus strains in Jammu region.

\section{Materials and Methods}

\section{Animals}

Suspected clinical cases: In the present study, suspected samples of Capripoxvirus infection were collected from various organized and unorganized farms, clinical cases and slaughterhouses of Jammu region.

\section{Collection of clinical samples}

A survey was carried out for investigating the occurrence of capripox infection in small ruminants from different parts of Jammu, Samba, Kathua, Udhampur, Reasi, Doda, Kishtwar, Rajouri and Poonch districts of Jammu division (except Ramban district) from June 2017 to November 2018. A total of 47 localities were visited and sheep and goats were investigated for occurrence of the disease. Clinical materials included scabs, skin lesions, or occasional incisional biopsies, and lesions from skin from Capripox suspected live or dead animals. The detailed clinical history, gross alterations of affected/ suspected animals were recorded and necessary photographs were also taken.

\section{Histopathological examination}

Tissue samples were preserved in $10 \%$ buffered formalin. All procedures were adopted from Luna (1968). Processing was done by routine alcohol-xylene dehydration and clearing. Embedding was done by low melting paraffin wax $\left(56-60^{\circ} \mathrm{C}\right)$. Tissue sectioning was done at 4-5 micron thickness with a rotary microtome. Sections were stained with routine Harris haematoxylin and eosin stains and mounted with DPX for observing the histomorphological changes.

\section{Results and Discussion}

\section{Clinical signs}

Whenever possible, clinical signs of sheeppox/ goatpox in the affected sheep and goat were closely monitored and recorded. The signs of the disease were observed to be distinctly variable in two phases. The acute febrile phase within the first few days (5-6 days) with developing cutaneous lesions and a less severe and prolonged phase associated with healing of cutaneous scars and possible self-recovery up to 5-6 weeks.

\section{Sheep}

Affected animals manifested a high rise in body temperature $\left(104-105.6^{\circ} \mathrm{F}\right)$ with the presence of copious occular discharge and conjunctivitis (Fig. 1A). Copious nasal exudations associated with rhinitis formed crusts over the external nares (Fig. 1B), causing considerable dyspnoea and showing signs of labored breathing. Animals appear lethargic, anorectic and often emaciated in prolonged illness. In severe cases death occurred within a few days of affection or with impairment of the respiratory system.

\section{Goats}

The clinical signs were more severe in goat than in sheep. Systemic signs manifested were high fever $\left(104-105.8^{\circ} \mathrm{F}\right)$, anorexia, depression and suspended rumination. 
Purulent conjunctivitis and blepharitis was commonly seen (Fig. 1C) and a discharge of mucopurulent exudates forming encrustations over the nares and lips (Fig. 1D). The mucous membranes appeared necrotic or ulcerated. Lymphadenopathy could be observed over the scapular and cervical lymph nodes. When the respiratory system was involved, severe dyspnoea and respiratory distress was evident. Death occurred in severe and terminal cases most commonly seen in the affected kids.

\section{Gross lesions from clinical and post- mortem studies}

\section{Cutaneous lesions}

\section{Sheep}

Initial lesions on the skin comprised mainly of erythematous macules (Fig. 2A) and papules (Fig. 2B) which were 0.5 to $3 \mathrm{~cm}$ in diameter. The papules then progressed into nodules (Fig. 2C) which formed hard masses. These often coalesced later to form larger nodules. An ulcerated and depressed central necrotic core soon formed, often covered with a necrotic crust. These crust covered lesions developed to thick scabs (Fig. 2D). The crusts were later sloughed off at certain places leaving an erythematous and ulcerated surface underneath with uneven borders/edges forming the characteristic pock lesions.

The later skin lesions characterized by a well demarcated, circumscribed pock lesion were distributed on the lips, cheeks, nostrils, head and neck and on any sparsely wooled areas.

Various developing lesions on the body were also found on the base of the tail, perineum, vulva and anus (Fig. 2E), mammary glands and teats (Fig. 2F), the inner thigh, abdomen and inguinal region (Fig. 2G). These could be seen subcutaneously even after the skinning as white, firm and circular lesions.

\section{Goats}

In case of goats, the skin lesions developed progressively as in sheep through erythematous macules and papules (Fig. 3A). There were abundant grayish white and firm papules that vary in size from 0.5 to $3 \mathrm{~cm}$ in diameter. The papules formed more elevated, circular and plateau-like nodules (Fig. 3B). The nodules leave a necrotic center and progressed to scabs (Fig. 3C). The scabs slough off in older healing lesions to leave characteristic circumscribed, ulcerated and cratered pock lesions (Fig. 3D).

The developing lesions were most predominantly seen on the hairless parts of the body including the eyelids, nostrils, muzzle, base of the tail and perineum including the anus or vulva (Fig. 3E), udder and teats (Fig. 3F) and on the ventral abdomen, medial aspect of the thighs, and inguinal regions (Fig. 3G). These lesions were seen even after skinning the animal from the subcutaneous side.

\section{Systemic lesions}

Two (2) sheep and four (4) goats were accessed for a thorough necropsy examination.

\section{Subcutaneous lesions}

\section{Sheep/Goats}

After skinning, congestion, haemorrhage, oedema, and necrosis were noticeable in the subcutaneous tissue particularly beneath the overlying lesions.

\section{Digestive system}

\section{Sheep/Goats}

Circumscribed grayish-white areas with 
ulcerative surface resembling 'gunshot wounds' were seen on the dorsal surface of the tongue associated with severe glossitis (Fig. 4A). Nodules were also seen on the lining of buccal mucosa. Nodular and firm gum lesions and gingivitis was also seen in one kid (Fig. 4B).

In the abomasum, circular grayish-white plaques measuring 1 to $3 \mathrm{~cm}$ across could be seen on the mucosa in both sheep (Fig. 4C) and goats (Fig. 4D). The lesions sometimes coalesced together to form larger plaques. In certain instances the plaques appeared circumscribed with a central depression. Mild catarrhal enteritis was evident in some animals.

In the liver of two sheep there were small, grayish-white, circular necrotic areas on the surface measuring up to 0.3 to $1 \mathrm{~cm}$ in diameter that appeared firm in consistency (Fig. 4E). The livers also appeared pale, mildly fatty with rounded edges, depicting a prominent lobular pattern. Similar liver lesions were observed in a goat; however, the necrotic areas appearing larger, measuring 0.3 to $3 \mathrm{~cm}$ across, and the edges appearing lighter, centrally depressed and diffusely merged with the surrounding parenchyma (Fig. 4F).

\section{Respiratory system}

\section{Sheep}

In the respiratory system, a consistent finding was the presence of multifocal pneumonia. Multiple, discrete, circular, grayish-white papules, nodules or plaques were present throughout the lung surface (Fig. 5A).

On cut section, the nodules or plaques were firm in consistency. The affected lungs were enlarged, oedematous and congested with irregular foci of consolidation. Severe fibrinous pleuritis on the dorsal lungs surface, with multifocal areas of consolidation and maculopapular lesions could be seen in one animal (Fig. 5B). The overlying trachea in all cases was congested.

\section{Goat}

Pock lesions were observed in the nasal passage which had a necrotic and cheesy core (Fig. 6A). The trachea appeared congested. The lungs appeared swollen, heavy and edematous having irregular foci of consolidation representing multifocal pneumonia.

There were multiple, raised but flat, variable sized, grayish-white papules and nodules present throughout the lung lobes (Fig. 6B). On cut section, the sub-pleural nodules presented with a cheesy core (Fig. 6C) resembling desiccated purulent exudation. The lesions appeared very firm in consistency with considerable sub-pleural fibrosis (Fig. 6D).

\section{Urinary system}

\section{Sheep/Goats}

In the affected animals, the kidney showed multiple, small, white necrotic foci (Fig. 7A). On cut sections, the cortex was pale and there was congestion in the cortico-medullary junction having a few necrotic foci (Fig. 7B).

\section{Histopathological examination}

\section{Skin}

Cutaneous histopathological specimens comprised of biopsy materials as well as tissues collected at necropsy. Lesions were similar in both sheep and goats and were comparable. 


\section{Sheep/Goats}

The encrusted scab was the most easily accessible biopsy material. Histological preparation of the scab showed a homogenously coagulated and degenerated hyalinized tissue with very less perceivable architecture. Masses of bacteria were also visible in isolated pockets within the tissue (Fig. 8A).

In viable tissues marked by initial gross lesions of macule and papule formation, microscopic lesions observed were acanthotic, parakeratotic and hyperkeratotic (Fig. 8B) changes visible in the epidermis. Hydropic degeneration was seen in the spinosum cells (Fig. 8C) which were distorted and swollen many times over with eosinophilic proteinaceous fluid like material and presence of eosinophilic intracytoplasmic inclusion bodies in most spinous cells (Fig. 8D). The inclusions were present within a more or less vacuolated cytoplasm. Some of these cells ruptured to form microvesicles (Fig. 8E). Inclusions were also noticed within the follicular epithelial cells (Fig. 8F).

In the older lesions underlined by gross pock lesions, the epithelium showed considerable degeneration and desquamation to form cratered ulcerations (Fig. 9A) with proliferating cells from beneath. There was marked vasculitis in the dermis and subcutis. Thrombosed blood vessels were commonly seen. The dermis contained few to massive infiltration of inflammatory cells comprising mainly of macrophages, lymphocytes and fibroblasts (Fig. 9B). Noticeable fibroplasia was also observed in the subcutis in some sections.

\section{Lungs}

\section{Sheep/Goats}

Microscopic changes corresponding to the pock nodules seen grossly were characterized by noticeable pleuritis and interlobular septal thickening. The pleura appeared thickened, oedematous and infiltrated with mononuclear cells. The parenchyma of the affected subpleural lobules was degenerated and surrounded (sequestered) by a thickened interlobular septae.

Infiltration of the mononuclear cells was evident in most cases. The degenerated alveoli were filled with an amorphous, eosoniphilic material obliterating their lumen (Fig. 10A). In certain areas massive fibrosis was noticed often replacing the functional alveolar tissue (Fig. 10B). The surrounding lung tissue outside the lesions was characterized by atelectasis and emphysema.

In the airways, proliferative bronchitis and bronchiolitis was evident. Bronchitis/ bronchiolitis were seen with partial obliteration of their lumen with cellular debris comprising of desquamated epithelial and inflammatory cells (Fig. 11A,B). In the bronchioles proliferative changes were also noted.

Hyperplasia of the bronchiolar epithelium was seen with the infiltration of polymorpho nuclear and mononuclear cells together with hyperplasia of the Bronchi Associated Lymphoid Tissue (BALT) (Fig. 11C-E). In some sections, metaplasia of the bronchiolar epithelium into rounded cells with rounded nuclei could also be seen (Fig. 11F).

Alveolitis was marked by the appearance of hyperplastic type II pneumocytes with round nuclei and abundant cytoplasm giving a gland-like appearance (alveolar foetalization).

There was also associated inter-alveolar thickening, congestion, oedema, fibrin deposition and few mononuclear infiltrations (Fig. 12A-C) typical of interstitial pneumonia. A necrotizing alveolitis could also be seen in 
certain sections characterized by widespread necrosis and sloughing of alveolar epithelium and fibrin deposition (Fig. 12D).

Sometimes indistinct eosinophilic inclusions could be seen in alveolar lumen (Fig. 13 A), and within bronchiolar epithelium (Fig. $13 \mathrm{~B}, \mathrm{C})$. In certain areas "sheep pox cells" or "Cellules claveleuses" with a vacuolated cytoplasm could be demonstrated in the alveolar interstitial areas and elsewhere (Fig. 13D).

\section{Liver}

\section{Sheep/Goats}

The primary lesion in the liver was capsular thickening, and subcapsular focal degeneration and/or necrosis of hepatocytes, corresponding to the gross papulo-nodular lesions on the liver surface. These areas sometimes appeared slightly depressed or elevated from the surface (Fig. 14A,B). Moderate mononuclear infiltrating cells in the liver capsule could also be seen in certain sections. The liver parenchyma beneath these lesions appears degenerated with marginal disruption of the hepatic cords (Fig. 14C). Hepatocytes are swollen, rounded with a vacuolar cytoplasm (Fig. 14D).

The sinusoidal spaces appear narrowed and sometimes not easily discernible. Some hepatocytes also present double nuclei depicting regenerating hepatocytes (Fig. 15A). In some sections, the changes observed in the hepatic lobules were consistent with massive lobular degeneration and necrosis (Fig. 15B) with central vein congestion.

The most striking and consistent feature was biliary hyperplasia and a reactive cholangitis. In the portal triads, mild to moderate periportal fibrosis (Fig. 16A) and reactive cholangitis typified by accumulation of mononuclear cells (Fig. 16B) was seen, especially around the bile ducts.

In most cases biliary hyperplasia and proliferation was quite evident. This was characterized by severe non-neoplastic adenomatous changes with moderate cellular infiltration and fibroplasias (Fig. 17A-D). The epithelial cells also demonstrated proliferative changes like hyperplasia and mitotic activities.

Within the triad areas cells resembling 'sheep pox cells' could be demonstrated with or without eosinophilic intracytoplasmic inclusions and having a vacuolated or 'punched-out' nuclei (Fig. 18A). Besides, within the proliferative biliary epithelial cells, eosinophilic intracytoplasmic inclusion bodies were abundantly demonstrated arranged singly, or in multiple numbers (Fig. 18B-J). These inclusions tend to appear in the basal part of the elongated columnar cells, enclosed sometimes in a clear vacuolar space within the cytoplasm.

\section{Abomasum \\ Sheep/Goats}

Mild degeneration and sloughing of the mucosal epithelial cells was observed corresponding to the plaques visible grossly (Fig. 19A). The serosal vasculature was congested (Fig. 19B). There was oedema in the submucosa and the endothelial cells within the serosal arteries that appeared to undergo vacuolar degeneration, and thrombosis in the venules was evident (Fig. 19C).

\section{Intestine}

\section{Sheep/Goats}

Microscopically the intestinal sections 
revealed atrophy of villi in certain places (Fig. 20A). Mild to severe inflammatory reaction was seen in lamina propria with accumulation of mononuclear cells (Fig. 20B). In certain mucosal glandular epithelial cells, eosinophilic intracytoplasmic inclusions (Fig. 20C) could be demonstrated. There were occasional eosinophils infiltrating within the lamina propria (Fig. 20D).

\section{Kidney}

\section{Sheep/Goats}

Microscopically, some of the glomeruli appear shrunken and atrophied, with increase in the glomerular space. The glomerular visceral epithelium show acute focal degenerative changes and are mostly lost (Fig. 21A). The capillaries appear congested and dilated.

The mesangial cells undergo proliferation giving an appearance of hypercellularity (Fig. 21B). The glomerular basement membrane appears to be thickened and duplicated with atrophy of glomerulus (Fig. 21C). The lesions appear indistinguishable to membranoproliferative glomerulonephritis.

Early degenerative lesions could also be seen in the cortical tubules. Affected tubules appear dilated with presence of proteinaceous materials in their lumen (Fig. 21D).

\section{Spleen/ Lymph nodes}

\section{Sheep/Goats}

Lymphoid depletion with decrease in the size and number of follicles, absence of germinal centers was prominently seen in the subcapsular regions of the spleen, leaving cystic spaces both in the sheep (Fig. 22A) and goats (Fig. 22B).
The bronchial lymph nodes similarly showed lymphoid depletion of cortical and paracortical lymphocytes, leaving cystic cavitations (Fig. 22C). In one goat, reactive germinal centers with hyperplasia could be observed in the bronchial lymph node (Fig. 22D).

\section{Clinical signs}

The SPPV and GTPV are epitheliotropic virus and causes systemic infection resulting in characteristic clinical signs and lesions (Murthy and Singh, 1971; Afshar et al., 1986; Embury-Hyatt et al., 2012 and Sharma et al., 2013). In the present study, the observed clinical signs in affected animals were similar to those described in the literature.

Worldwide, similar clinical signs were observed by Daoud (1997) in Jordan; Davies and Otema (1981) in Kenya; Achour et al., (2000) in Algeria; Singh et al., (2007) in India; Sharawi et al., (2011) and Abd-Elfatah et al., (2018) in Egypt; Chanie (2011) in Ethiopia; Zangana and Abdullah (2013) in Iraq; Hamouda et al., (2017) in Saudi Arabia.

Besides, the clinical signs observed in the goats were similar or more severe when compared to those observed in sheep. The disease is otherwise said to be milder in goats when compared to that in sheep (Ginn et al., 2007), while on the other hand morbidity of Indian Goatpoxvirus isolates are considered to be more severe (Bowden et al., 2008).

Because the disease was observed to be species specific, when either goats or sheep were affected in co-populated flocks, it was initially assumed that all the goats were affected with specific GTPV strains and those in the sheep were affected with SPPV strains.

It is likely that the pathogenicity of both strains were different, and therefore would 
manifest difference in severity of the disease.

Besides, other variable factors may also contribute to differences in severity of infection- like differences in the immune status of the animals, strain, dose of infection, etc. (Bowden et al., 2008; OIE, 2012).

\section{Cutaneous lesions}

In the present study, gross lesions were observed prominently on the skin of the affected animals. Overall the gross skin lesions observed in the present study included papules, nodules and scab formation with no prominent or frank vesicular and pustular stages.

Skin lesions in both sheep and goat observed during ante-/ post-mortem examination comprised of an occasional erythematous macule which transformed readily to papules that were 0.5 to $2 \mathrm{~cm}$ in diameter. The cut sections of the papules appeared gray and firm as were reported by Pawaiya et al., (2008). The pathogenesis and development of the papule has been attributed to proliferation of keratinocytes and sub epidermal edema that produce an elevation of the lesion above the level of normal skin (Zachary and Mc Gavin, 2012).

These often coalesced to form firm nodules as described by Afshar et al., (1986). Ulcerated lesions were crust covered and the thick scabs sloughed off eventually leaving an erythematous and ulcerated surface beneath. The later skin lesions appeared as well defined typical circumscribed pock lesions. Descriptions of the lesion size in the literature vary from 0.4 to $3 \mathrm{~cm}$ (Davies, 1976; Joshi et al., 1999; Zangana and Abdullah, 2013). Similar lesions of papules, nodules and scab on the sparsely wooled/ hairless portions of the skin in sheep and goat pox were also reported by earlier authors (Mohammed et al., 1982; Saha et al., 1985; Afshar et al., 1986;
Nagpal et al., 1990; Joshi et al., 1999; Rashid et al., 2002; Dutta et al., 2002; Bowden et al., 2008; Rana et al., 2005; Pawaiya et al., 2008; Babuik et al., 2009; Beard et al., 2010; Bhanuprakash et al., 2010; Chanie, 2011; Verma et al., 2011; El-Sabagh et al., 2014 and Manjunatha et al., 2015).

In the present study the observation of vesicular and pustular stages were not apparently evident as reported earlier (Vegad and Sharma, 1970; Murthy and Singh, 1971; Davies, 1976; Afshar et al., 1986; Bowden et al., 2008 and Zro et al., 2014). With exception of a few microvesicles left behind by ruptured prickle cells, no prominent vesicle formation or frank vesicular stage was evident. Although bacterial aggregates as colonies within the epidermis was apparent, they were only numerous in scab biopsies that were shed off. The necrosed epidermis as a squeal to ischaemic necrosis is often invaded by bacteria (Jensen et al., 1987).

The vesicular stage as an integral lesion has been described by various earlier workers (Ginn et al., 2007; Yeruham et al., 2007; Peer et al., 2008; Manjunatha Reddy et al., 2015). However, Ginn et al., (2007) remarked that the vesicles are umblicated and being multilocular, yielding only a small amount of fluid when punctured. In addition, the pustular lesions, both alone (Govindarajan et al., 2005 and Singh et al., 2007) or in combination with nodules (Mondal et al., 2004) were also reported previously. However, the primary lesions of vesicles and pustules are observed to be fragile and often transient lasting only hours and so are difficult to identity and collect in biopsy samples (McGavin and Zachary, 2007). Similar observations were also made with the cutaneous lesions of orf infection in goats- as inconspicuous and associated transiently in early infection; they sometimes were visible as tiny, guttate vesicles (Nashiruddullah, 2014). Since the observations in the present 
study were based on spontaneous clinical cases, the continuous and progressive development stages of lesions were difficult to describe. In the animal flocks it was usual to see a mixture of cutaneous stages in affected animals and not consistent in all animals examined, and perhaps were related to the stage of infection. Sometimes a mixture of many stages was presented within the same animal. The progressive developmental stages could be better monitored only with experimental infection under controlled conditions, although the pustular stage indicates a pyogenic contamination overlying the lesion. In many reports, myiasis (OIE, 2017) has also been described as an associated complication where flies lay eggs on festering pock lesions to develop into maggoted wounds.

The skin lesions were observed throughout the body including lips, cheeks, nostrils, eyelids, head and neck. On the body they were found mostly on the inner thigh, base of the tail, perineum, udder/teats and inguinal region. The lesions were most prominent on the wool less/ hairless parts of the body.

Capripoxvirus being epitheliotropic, it induces lesions by a variety of mechanisms viz. dysfunction and death of dendritic and epithelial cells of the skin (McGavin and Zachary, 2007). Microscopically, the lesions in the skin observed were mainly of acanthosis, parakeratosis and hyperkeratosis. The epithelial changes, particularly in the prickle cell layer were typified with vacuolar degeneration, microvesiculation and intracytoplasmic inclusions. Replication of poxviruses occurs predominantly, if not exclusively, in the cytoplasm (MacLachlan and Dubovi, 2011) and hence inclusions are intracytoplasmic.

To achieve this independence from the cell nucleus, poxviruses, unlike other DNA viruses, have evolved to encode the enzymes required for transcription and replication of the viral genome, several of which must be carried in the virion itself. The scabs appeared hyalinized and could remain a source of infection as they are shed in the environment.

Along with the degeneration and desquamation of proliferating epithelial cells, the underlying developing lesions were marked by a progressive buildup of infiltrating inflammatory cells and the development of vasculitis beneath the epidermis. Capripoxviruses encode for genes homologous for epidermal growth factor (EGF) viral proteins (Tulman et al., 2002) and these proteins are attributed to epidermal hyperplasia (MacLachlan and Dubovi, 2011). For some poxviruses, epithelial hyperplasia is a dominant clinical manifestation and may be a consequence of a more potent form of the poxvirus epidermal growth factor homologue. Epidermal growth factor (EGF) regulates cell differentiation and proliferation in a number of cell types by binding to the ErbB family of receptors (Stein and Staros, 2000). Upon ligand binding, these receptor tyrosine kinases initiate a number of signaling pathways, including the MAPK pathway, which results in cell growth and differentiation (Tzahar et al., 1998).

The epitheliotropic Capripoxvirus induces skin lesions by a variety of mechanisms. Subsequent to pox virus invasion the resultant vasculitis causes ischemic necrosis of the epidermis, leading to necrosis and scab formation, a fact substantiated by the observations of Abdel-Ghaffar and Hassanein (2009). The severe necrotizing vasculitis in arterioles and post-capillary venules is believed to be due to a probable immune complex deposition rather than the presence of virus particles in the endothelial cells (Ginn et al., 2007). Immunohistochemical detection of sheep pox virus antigen also confirms 
antigen-antibody complexes in walls of the blood cells typical of an Arthus reaction and the presence of CD172A+ neutrophils around the pox lesions (Gulbahar et al., 2000; Gulbahar et al., 2006).

The characteristic eosinophilic intracytoplasmic inclusion bodies found in the prickle cells of skin was akin with the earlier reports (Nayak et al., 1984; Afshar et al., 1986; Guofu et al., 2004; Singh et al., 2007; Zhou et al., 2007; Pawaiya et al., 2008; Verma et al., 2011; Embury-Hyatt et al., 2012; Manjunatha Reddy et al., 2015). Basophilic intracytoplasmic inclusion bodies have been also described (Embury-Hyatt et al., 2012).

The erythematous macular stage is essentially an early inflammatory dermal response, while the papular stage is marked by infiltrating mononuclear cells (Ginn, et al., 2007). A typical cell has been described, called the "sheep-pox cells" or "cellules claveleuses" of Borrel that are virus infected monocytes, macrophages and fibroblasts (Ginn et al., 2007), most of which contain intracytoplasmic inclusions and having a chromatin marginated or punched out nuclei. These cells were, however, not visible in the dermal tissue of animals accessed in the present study, and likely would be dependent with the stage of infection. Likewise, many others (Hailat et al., 1994; Yeruham et al., 2007; Verma et al., 2011; Chanie, 2011; Zangana and Abdullah, 2013; Manjunatha Reddy et al., 2015; Aswini, 2015) noted the absence of sheep pox cells in the cutaneous tissue.

Although transmission of Capripoxvirus is believed to occur primarily via respiratory aerosol, however, intradermal inoculation results in shorter incubation period and similar disease manifestation (Kitching and Taylor, 1985). Controlled qPCR based experimental studies in sheep and goats infected with respective Capripoxvirus isolates have shown that onset of fever commence from 5-6 days and measurable viremia started by 4 days in goats and 6 days in sheep; however, infectious viruses could only be isolated 1-2 days afterwards (Bowden et al., 2008).

\section{Digestive system}

In the digestive system, although gross lesions were noticed on the tongue, dental pad and buccal mucosa of affected animals, no histopathological investigation was possible as these lesions were absent in the necropsied specimens. Contextual references were found to such lesions being described in the literature and the presence of typical lesions including hydropic degeneration and microvesicle formation, and the occasional intracytoplasmic inclusion (Abdel-Ghaffar and Hassanein, 2009; Verma et al., 2011; Sharma et al., 2013; Jayasri, 2015). Vesicles with ulcerative lesions (Murthy and Singh, 1971) or eruptions with ulcerative lesions (Kataria and Sharma, 1992) or eruptions alone (Wei et al., 2010; Raina et al., 2003; Kumar and Gupta, 2015) on the mucosa of the tongue have also been described.

Similar lesions have also been described in the rumen (Yeruham et al., 2007; EmburyHyatt et al., 2012; Jayasri, 2015; Aswini, 2015).

In the present study, the lesions characterized as grayish-white plaques observed in the abomasum and on the liver are archetypal to the lesions associated with capripox infection. These were in agreement with the observations of Pawaiya et al., (2008), Babuik et al., (2009), Wei et al., (2010) and EmburyHyatt et al., (2012).

Desquamation of epithelium and vacuolar degeneration noticed conformed to the findings of others (Kumar and Gupta, 2015; 
Jayasri, 2015; Karapinar et al., 2017). However, no inclusions were observed in the abomasums as reported by Kumar and Gupta (2015), the presence of which could be variably associated with the stage of infection. It was worthy to note that the underlying vasculature appeared to be markedly affected.

Thrombosis and vasculitis could be seen in the venules, while endothelial vacuolation was observed in the arteries. These observations were also corroborated by others (Abdel-Ghaffar and Hassanein, 2009; Jayasri, 2015). Fibrinoid necrosis of vessel wall and presence of inclusion bodies were additional lesions seen by Abdel-Ghaffar and Hassanein (2009).

It is speculated that the vascular lesions could lead to the ischaemic and degenerative lesions in the mucosa and responsible for the plaques observed grossly. In an experimental study, tissue tropism in sheep and goats infected with respective Capripoxviruses, the discrete nodules in the alimentary tract including those in the abomasums were observed from $10 \mathrm{dpi}$ in both sheep and goats (Bowden et al., 2008).

The liver lesions were similar to the typical lesions of capripox infection reported by many workers (Murthy and Singh, 1971; Sharma et al., 1986; Sadhukhan et al., 1999; Verma et al., 2011; Sajid et al., 2012; Embury-Hyatt et al., 2012; Jayasri, 2015; Aswini, 2015).

The plaque-like lesions in the liver were marked by capsular thickening and a predominantly subcapsular degeneration of the parenchyma as has been recorded by Embury-Hyatt et al., (2012). In an experimental study, Bowden et al., (2008) observed that the well circumscribed, pale, subcapsular lesions in the liver and kidneys started to appear in goats from 11 dpi. Bile duct hyperplasia and increased mitotic activity of the hepatocytes indicate the proliferative changes undergoing in the liver. Bile duct hyperplasia has been occasionally reported in the literature.

These have been described only in goats with presence of inclusions when both sheep/goats were experimentally infected (Embury-Hyatt et al., 2012) or in spontaneously affected goats (Sajid et al., 2012) or sheep (Aswini, 2015). The proliferative activity of the epithelial cells may be due to the expression of viral protein homologues of EGF (Epidermal Growth Factor).

\section{Respiratory system}

At necropsy examination, along with the multiple dermal papules, all of the animals in the present study affected with Capripoxvirus revealed firm grey nodular pock lesions throughout the lungs. Similar lesions have been described previously (Mondal et al., 2004; Gulbahar et al., 2006; Roy et al., 2008; Aswini, 2015; Jayasri, 2015). Affected animals develop multiple consolidated pulmonary lesions (Yager and Scott, 1985) and these lesions are characteristic of generalized sheep pox infection, often dubbed as a malignant form of the disease.

It is estimated that approximately one-third of sheep pox affected animals develop multiple, consolidated pulmonary lesions (Yager and Scott, 1985). Although very seldom described in the literature, a severe fibrinous pleuropneumonia presently seen in one young sheep was similar to the description of Ozmen et al., (2009) who reported it to be prominently associated in sheep pox affected lambs. Bowden et al., (2008) observed that lung lesions are apparent from 6 dpi when sheep and goats were experimentally infected with respective Capripoxviruses, and that the initial red spots progressed to nodules by $8-10$ 
dpi. Microscopic lesions recorded in the study were similar to previous descriptions in the literature. The pock nodules described by Beytut, (2010) were often surrounded by a zone of hyperaemia, while some nodules coalesced to form lymphoma-like lesions.

The surface lesions were very well demarcated or fairly surrounded by connective tissue, as also observed by others (Dar et al., 2012; Beytut, 2010) and extended into the lung parenchyma. Within the pock lesions, the interalveolar septae were thickened as also described by others (Bhowmick et al., 1986; Joshi et al., 1992; Bhanuprakash et al., 2006; Beytut, 2010; Dar et al., 2012) and often containing amorphous eosinophilic materials in the alveolar lumen (Bhanuprakash et al., 2006; Beytut (2010).

Thickened pleura and septa were underlined by significant fibrosis, but devoid of inflammatory cellular infiltration, a fact also endorsed by Beytut (2010) but observed contrarily by Dar et al., (2012). The lesion demarcated areas appeared degenerated and necrosed as those observed by Beytut (2010); but necrosis have been described as not being a conspicuous feature (Singh et al., 1979).

Histopathologic descriptions in the deeper parenchyma were characterized by a proliferative bronchiolitis and alveolitis as previously described (Ginn et al., 2007; Beytut, 2010). A striking feature of lung pathology was the gland-like proliferation of the bronchiolar lining epithelium and their metaplasia to type II pneumocytes. This has been observed by others (Sadhukhan et al., 1999; Pawaiya et al., 2008; Wei et al., 2010; Sajid et al., 2012; Dar et al., 2012; Jayasri, 2015) and a subject of investigation (Beytut, 2010) through expression investigation of pulmonary surfactant proteins. Immunochemical markers successfully demonstrated the intense expression of surfactant proteins in the cytoplasm of hyperplastic type II pneumocytes typified by a gland like appearance (Beytut, 2010).

Inter-alveolar interstitial thickening seen in the present study were often underlined by fibrin deposition and indicative of an acute inflammatory response and increase in vascular permeability. The hyperplasia of the bronchi associated lymphoid tissue is also described by other workers (Bhanuprakash et al., 2006).

The pulmonary tissue showed abundance of inclusion laden cells both in the bronchial epithelial and in some mononuclear cells. This has been observed by many others as well (Murray et al., 1973; Yager and Scott, 1985; Afshar et al., 1986; Gulbahar et al., 2006; Tarello and Kinne, 2007; Haligur and Ozmen, 2009; Abdel-Ghaffar and Hassanein, 2009; Beytut, 2010; Verma et al., 2011; Dar et al., 2012; Sharma et al., 2013; Jayasri, 2015).

\section{Urinary system}

In the affected animals, the multiple, small, pale necrotic foci on the kidneys were similar with the reports of Murthy and Singh (1971), Kataria and Sharma (1992), Malik et al., (1998) and Sharma et al., (2008). Histological sections revealed interstitial nephritis similar to those observed in sheep and goats by previous workers (Embury-Hyatt et al., 2012; Jayasri, 2015). It is postulated that an inflammatory response secondary to viremia and involvement of the kidney tubules lead to a pronounced interstitial reaction (Vegad and Katiyar, 1998). In the glomerulus, proliferative lesions were also earlier noticed by Pawaiya et al., (2008) and Sajid et al., (2012). 


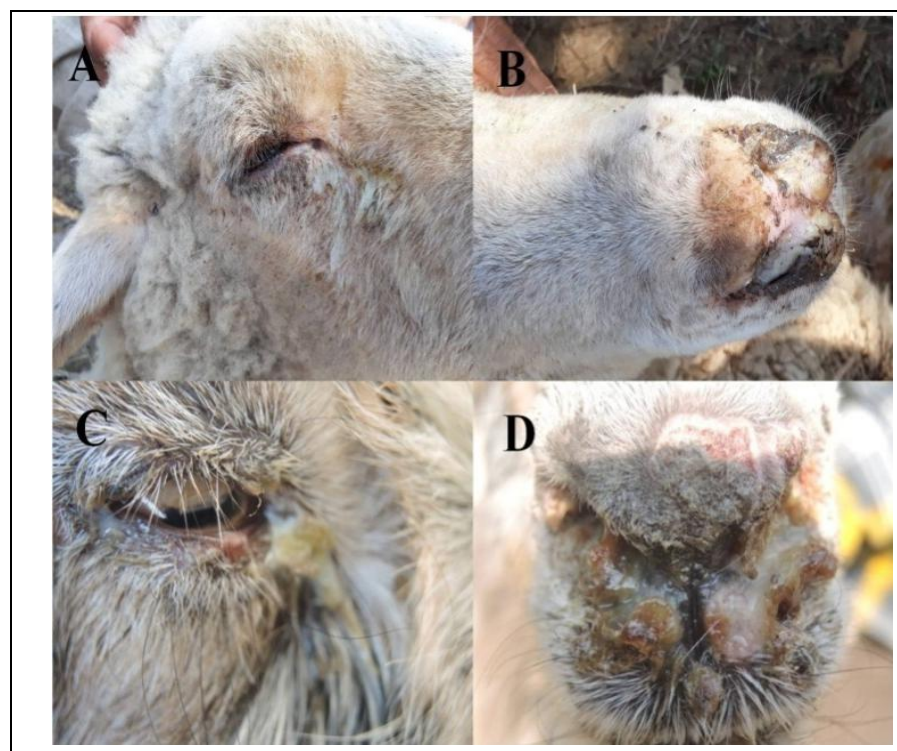

Fig.1 Clinical signs of capripox infection in small ruminants. (A) Copious occular discharge and conjunctivitis in sheep; (B) Mucopurulent nasal discharge often leading to encrustations causing difficulty in breathing in sheep; (C) Severe conjunctivitis and blepharitis in goats; (D) Mucopurulent nasal discharges forming encrustations in goats.

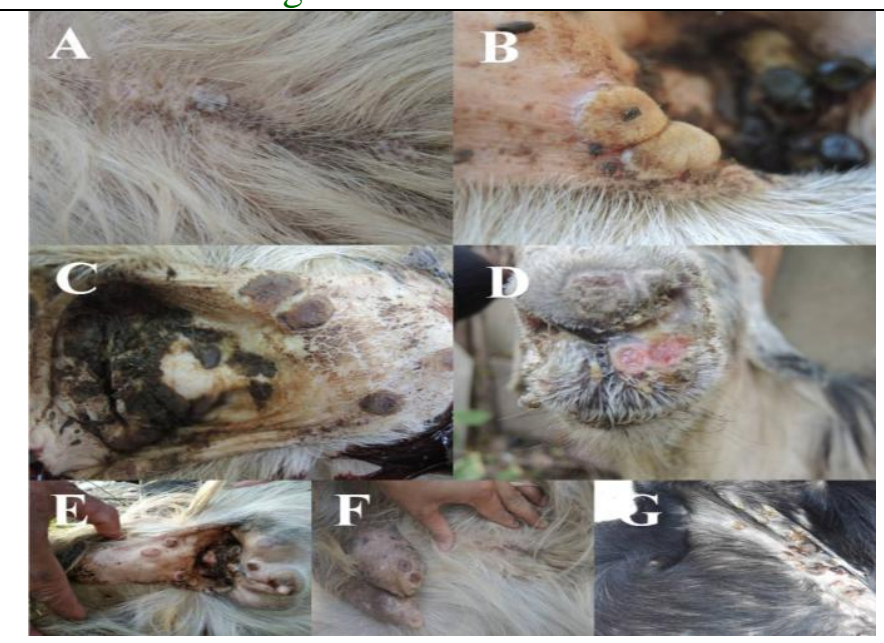

Fig.3 Developing cutaneous lesions of capripox in goats. (A) Papules; (B) Elevated, circular and plateau-like nodules; (C) Encrusted scabs; (D) Circumscribed, ulcerated and cratered pock lesions; (E) Pock lesions on base of the tail, perineum, vulva and anus; (F) Scab lesions on mammary glands and teats; (G) Scab lesions on abdomen and inguinal regions.

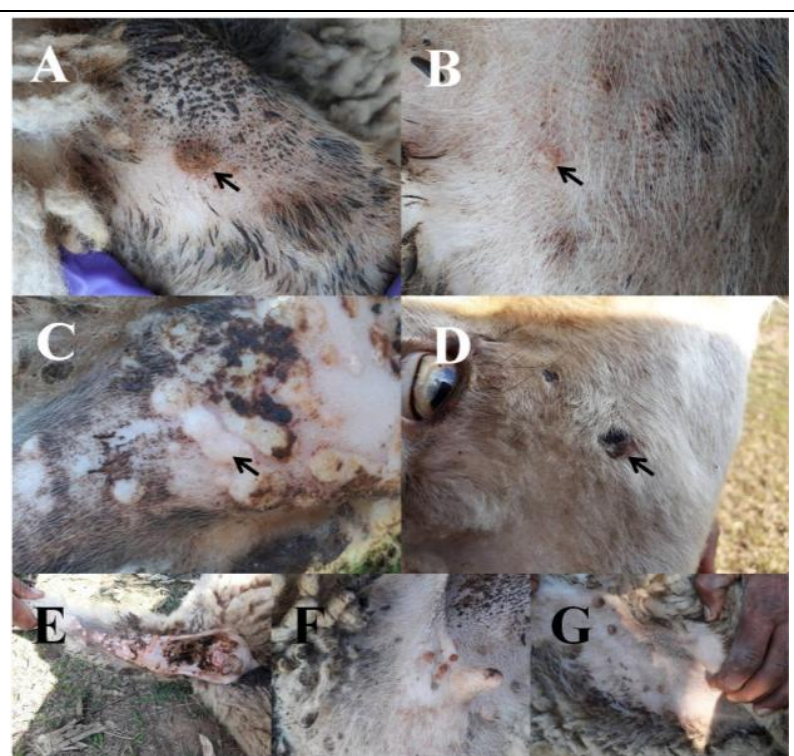

Fig.2 Developing cutaneous lesions of capripox in sheep. (A) Erythematous macules; (B) Papules; (C) Nodules; (D) Encrusted scabs; (E) Pock lesions on base of the tail, perineum, vulva and anus; (F) Scab lesions on mammary glands and teats; (G) Scab lesions on abdomen and inguinal regions.

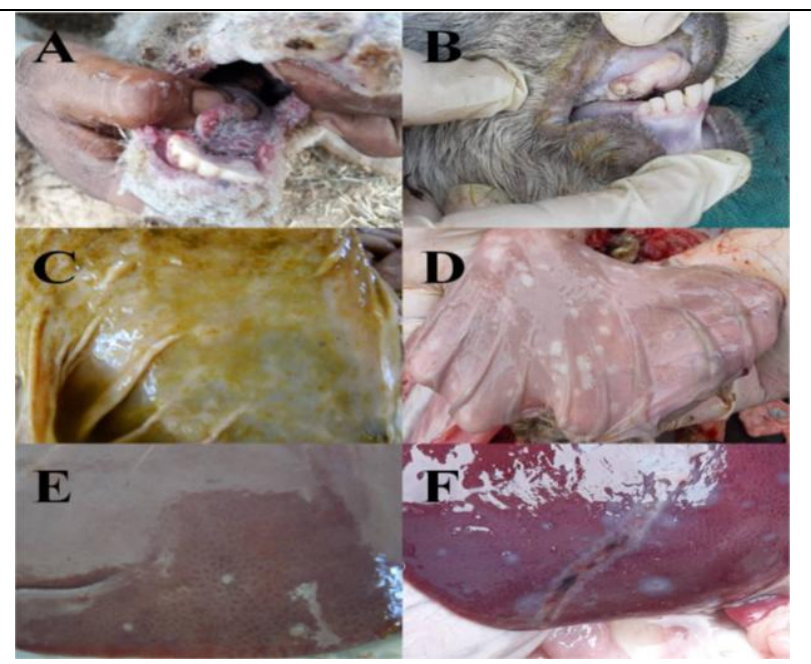

Fig.4 Lesions of capripox in the alimentary tract in small ruminants. (A) Circumscribed, ulcerative lingual lesions resembling 'gunshot wounds' and assosiated glossitis in a sheep; (B) Nodular, firm gum lesions and gingivitis in a kid; (C) Circular grayish-white plaques on the mucosa of the abomasums in sheep; (D) Plaques on the abomasum in a kid; (E) Small, grayish-white, circular necrotic areas in the liver of a sheep; (F) Circular necrotic lesions, with a central depression and diffuse boundary in the liver of a goat. 


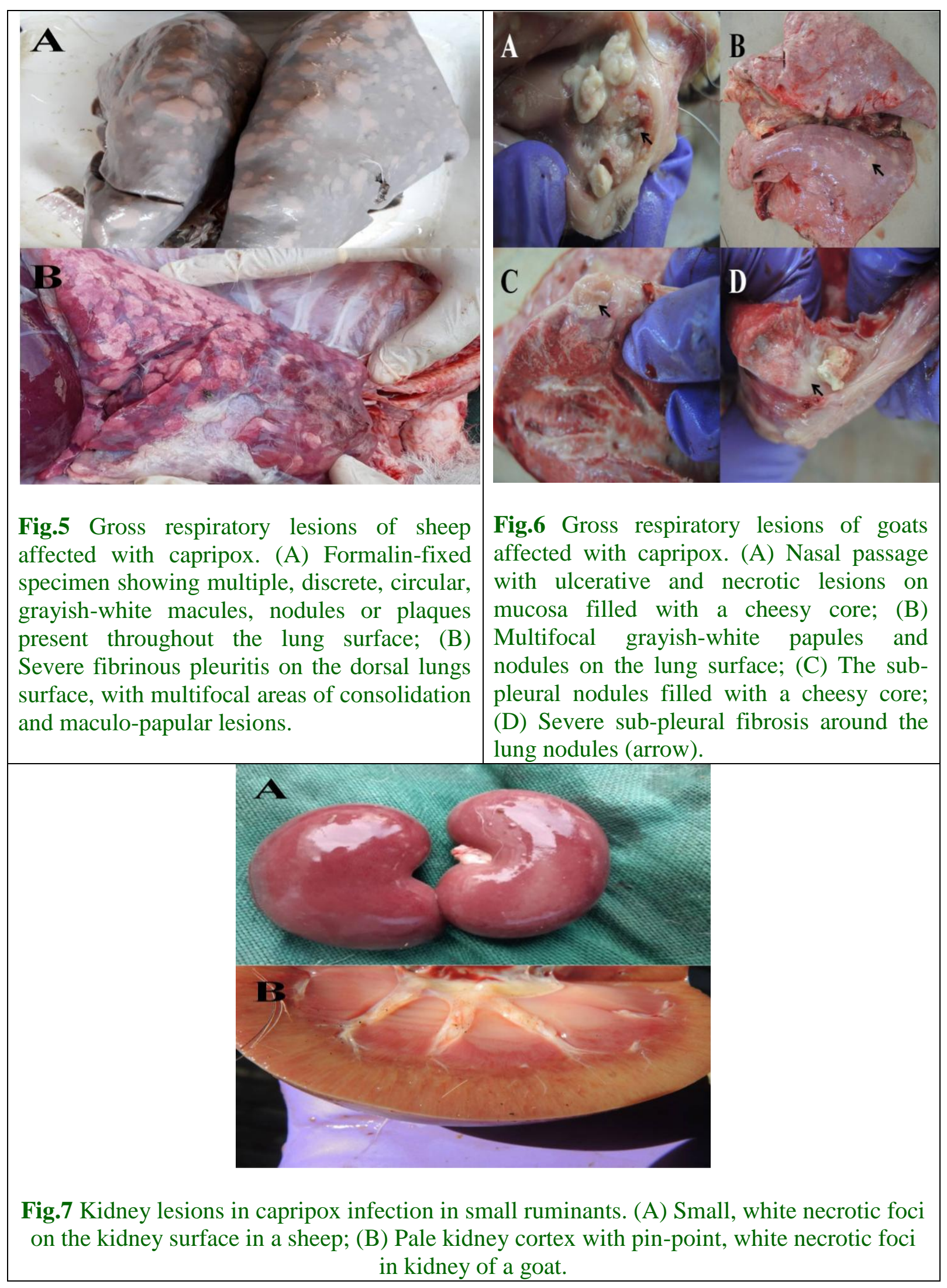




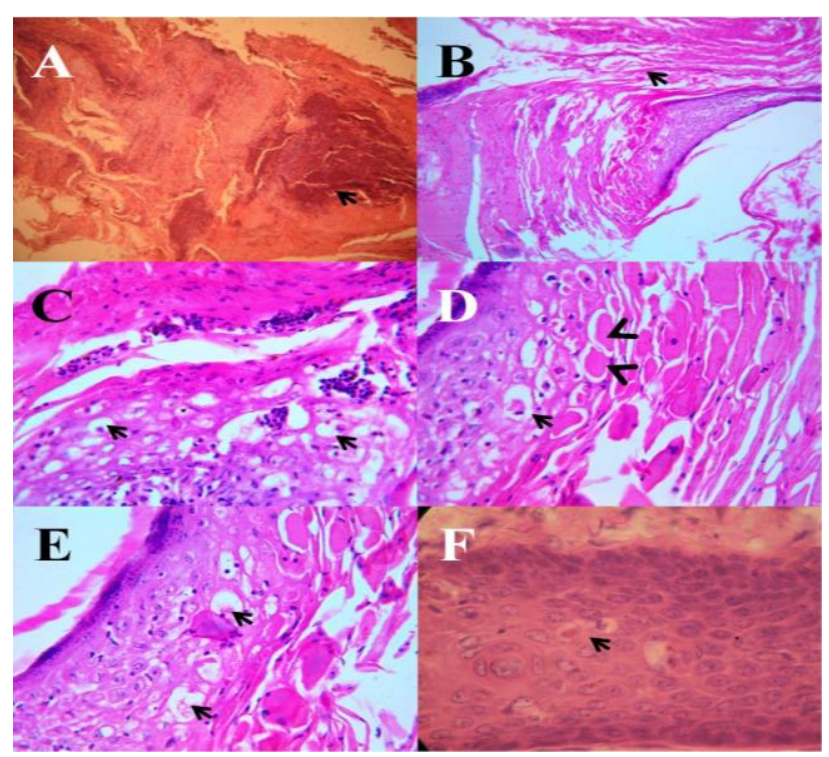

Fig.8 Initial microscopic lesions of Capripox infection in cutaneous tissue of small ruminants. (A) Biopsy of encrusted scab from a sheep showing degenerated and hyalinized tissue with presence of a large bacterial mass (arrow). H\&E, 100X; (B) Skin biopsy from a sheep showing hyperkeratinization (arrow). H\&E, 100X; (C) Hydropic degeneration (arrow) of spinosum cells in the epidermis. H\&E, 400X; (D) Presence of proteinaceous fluid (arrowheads) and eosinophilic intracytoplasmic inclusion bodies in spinous cells (arrow). H\&E, 400X; (E) distended and ruptured spinous cells leading to formation of microvescicles (arrows). H\&E, 400X; (F) Eosinophilic intracytoplasmic inclusion bodies in follicular epithelial cells (arrow) of a goat. $\mathrm{H} \& \mathrm{E}, 400 \mathrm{X}$

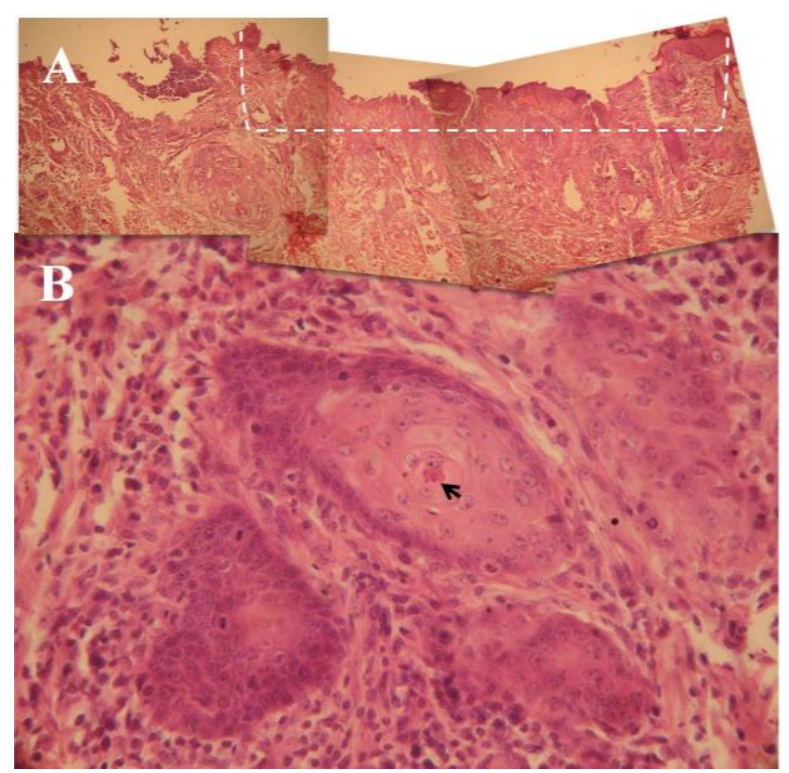

Fig.9 Progressive microscopic lesions of Capripox associated skin lesions in small ruminants. (A) Composite photomicrograph depicting degeneration and desquamation of epithelium forming cratered ulcerations and reactive dermis. H\&E, 100X; (B) Massive infiltration of macrophages, lymphocytes and fibroblasts in the dermis. Eosinophilic intracytoplasmic inclusion bodies were seen in the follicular epithelial cells. H\&E, 400X 


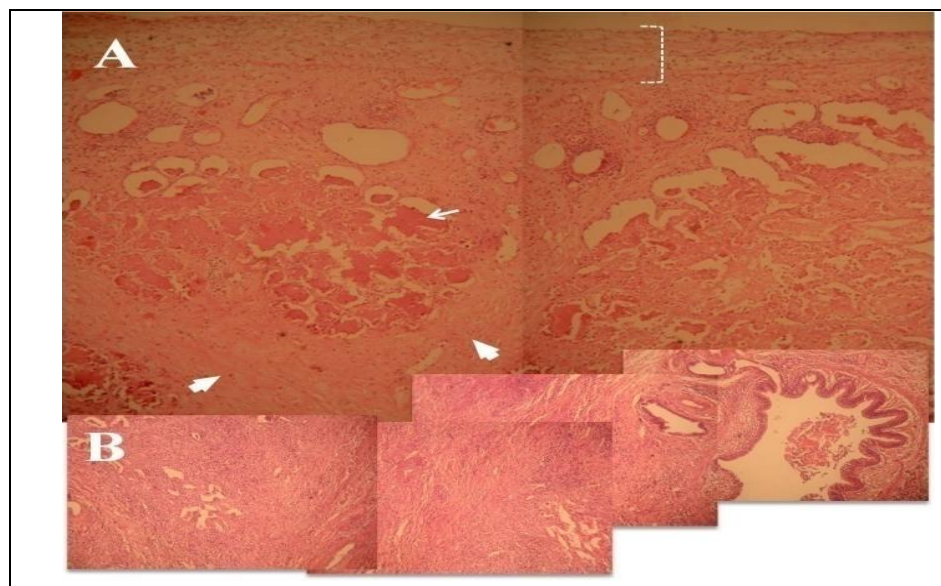

Fig.10 Histopathological lung lesions of capripox infection in sheep and goats. (A) Composite photomicrographs of sub-pleural nodular lesions in a goat depicting pleuritis characterized by a thickened pleura (bracket), oedema and mononuclear cell infiltration. Alveoli in affected lobules undergo degeneration with presence of amorphous material (arrow) and surrounded by a thickened interlobular septa (thick arrows). H\&E, 100X; (B) Composite photomicrograph of an affected lobule in sheep showing massive and extensive fibrosis replacing the normal functional tissue. H\&E, 100X.

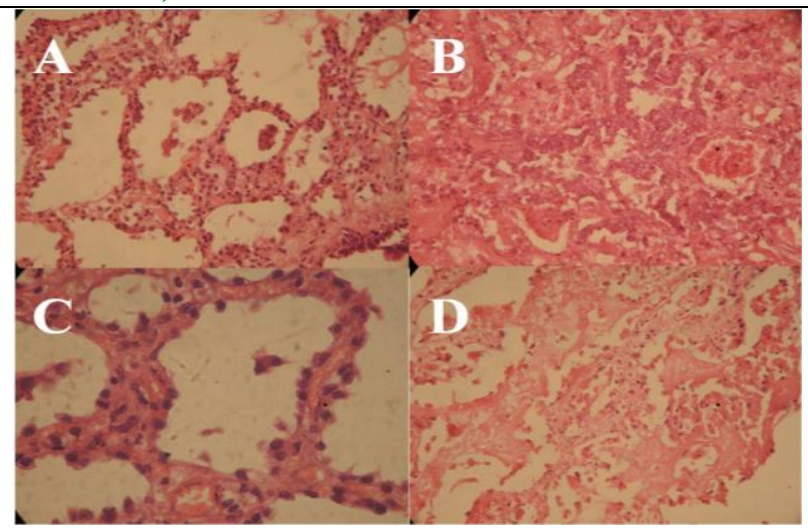

Fig.12 Alveolar histopathological lesions of capripox infection in sheep and goats. (A, B) Alveolar epithelium undergoing metaplasia to type II pneumocytes with round nuclei and abundant cytoplasm in goat and sheep respectively. H\&E, 400X; (C) Inter-alveolar thickening, oedema, fibrin deposition and epithelial metaplasia to Type-II pneumocytes in a goat. H\&E, $1000 \mathrm{X}$; (D) Necrotizing alveolitis characterized by necrosis and sloughing of alveolar epithelium and fibrin deposition in a sheep. H\&E, 400X.

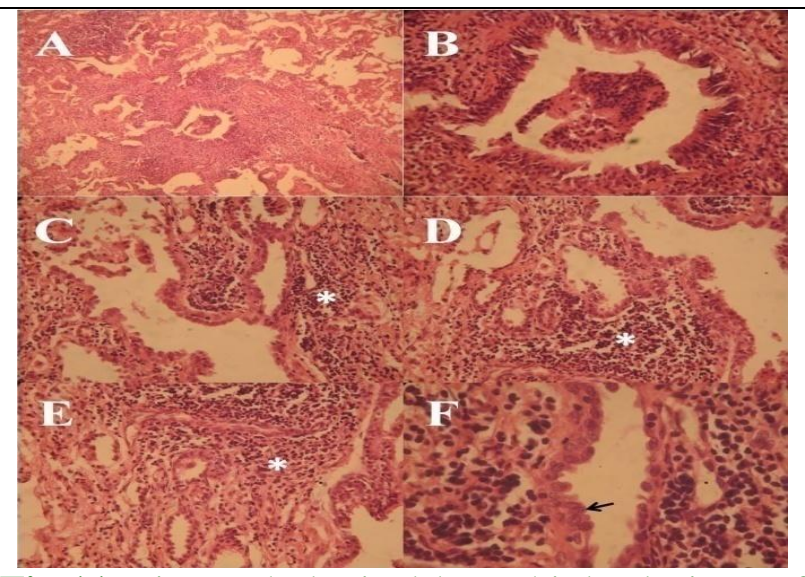

Fig.11 Histopathological bronchiolar lesions of capripox in sheep and goats. (A) Bronchiolitis in a sheep with partial obliteration of lumen with desquamated and inflammatory cells. H\&E, 100X; (B) Higher magnification of 'A' showing epithelial hyperplasia and submucosal infiltration. H\&E, 400X; (C-E) Bronchioles in a goat showing hyperplastic mucosa, proliferation of BALT and other inflammatory cells. H\&E, 400X; (F) Metaplasia of bronchiolar epithelium into rounded cells with rounded nuclei. $H \& E$, 1000X.

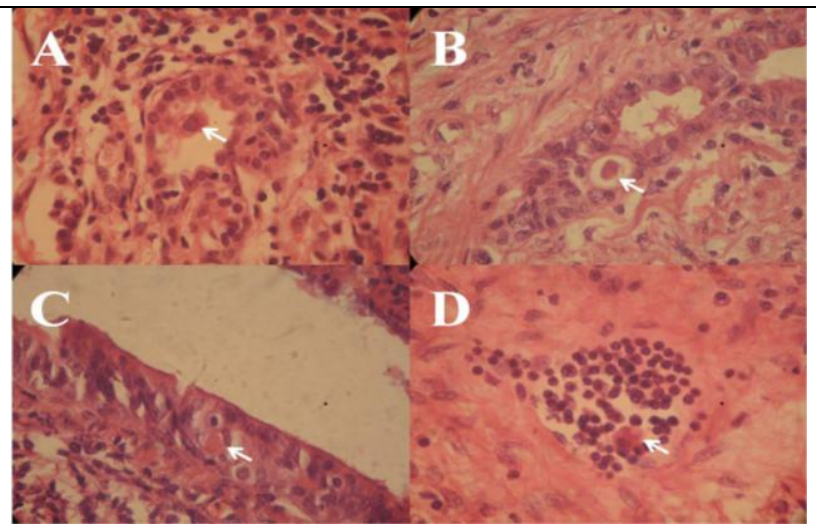

Fig.13 Capripox associated inclusions in lungs of small ruminants. (A) Cells with indistinct intracytoplasmic inclusions in alveolar lumen; $(\mathrm{B}, \mathrm{C})$ Within bronchiolar epithelium; (D) In inter-alveolar interstitium. All sections stained with H\&E, 1000X 


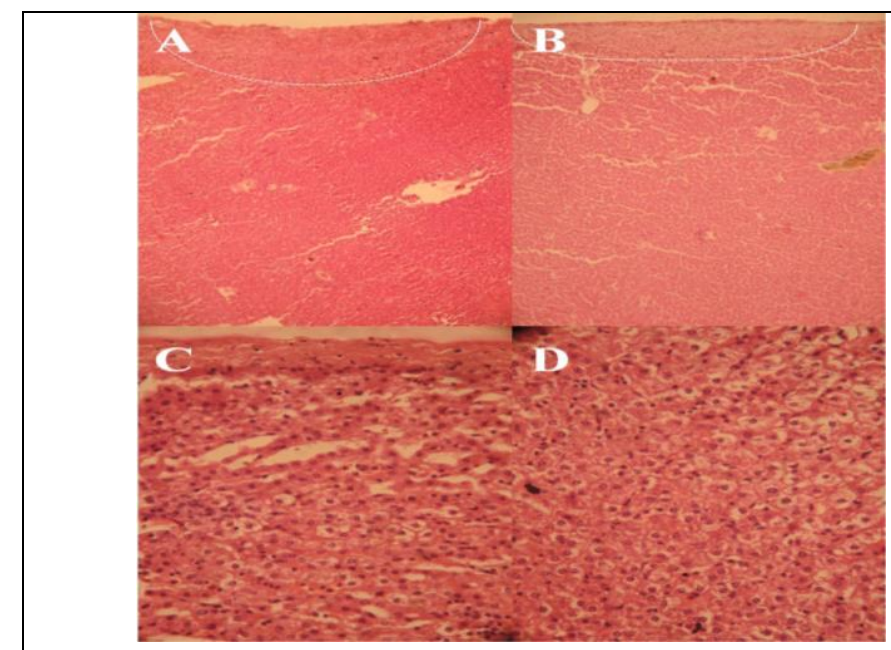

Fig.14 Capsular and sub-capsular lesions of capripox infection in liver of sheep and goats. (A) Subcapsular focal necrosis in a sheep. H\&E, 100X; (B) Subcapsular focal necrosis in a goat. H\&E, 100X; (C) Hepatocytic degeneration with marginal disruption of the hepatic cords. Note mononuclear infiltrates in thickened capsule. H\&E, 400X; (D) Swollen and vacuolated hepatocytes. H\&E, 400X.

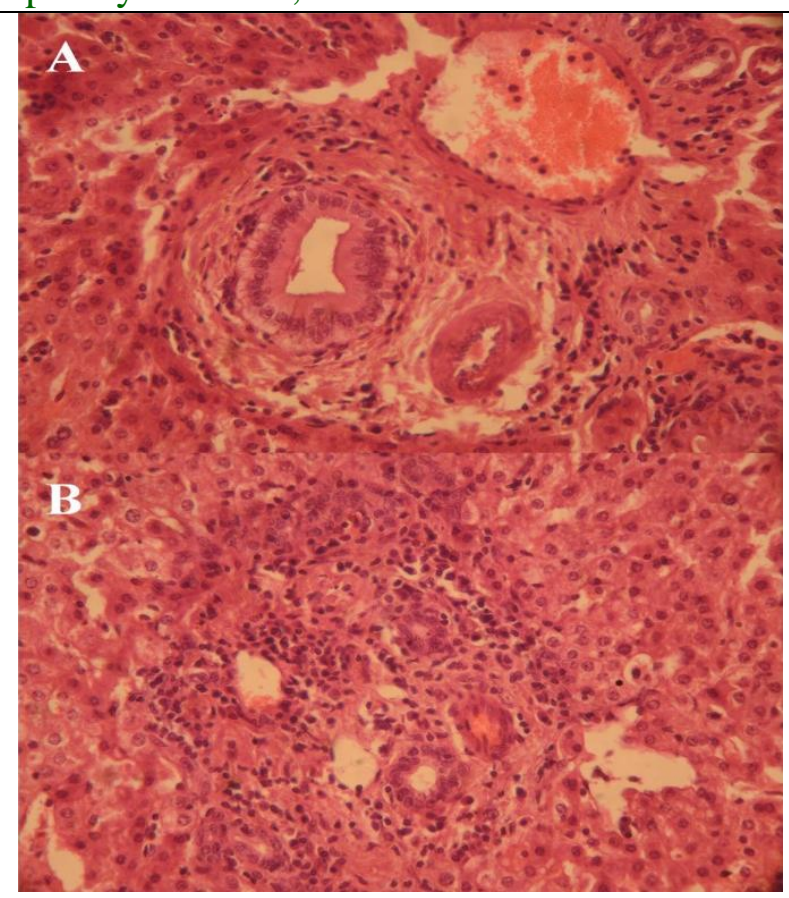

Fig.16 Microscopic changes in biliary ducts associated with capripox infection. (A) Moderate periportal fibrosis in a goat, H\&E, 400X; (B) Reactive cholangitis showing infiltration of mononuclear cells in the triad areas. H\&E, 400X.

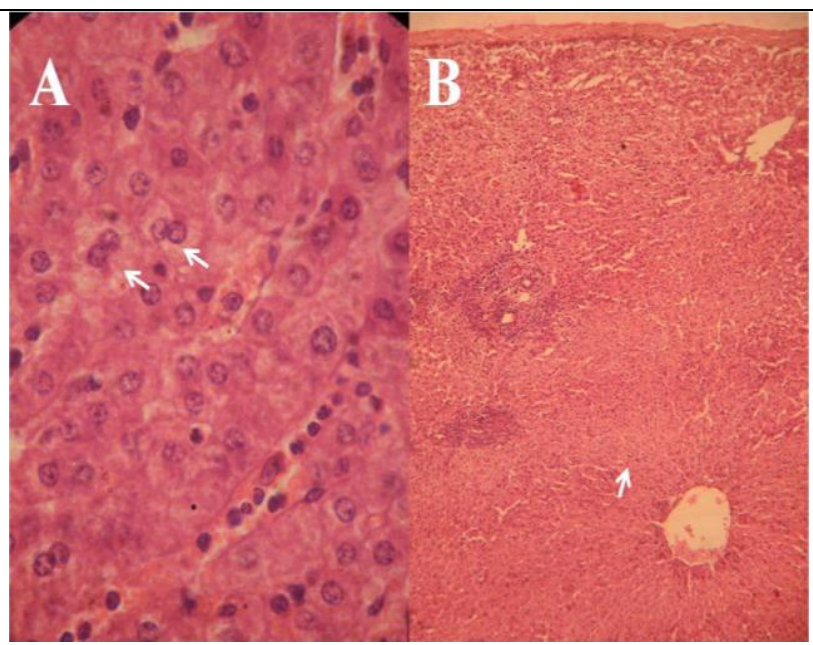

Fig.15 Histopathological lesions of capripox infection in liver of sheep and goats (A) Hepatocytes with double nuclei. H\&E, 1000X; (B) Massive lobular degeneration. H\&E, 100X.

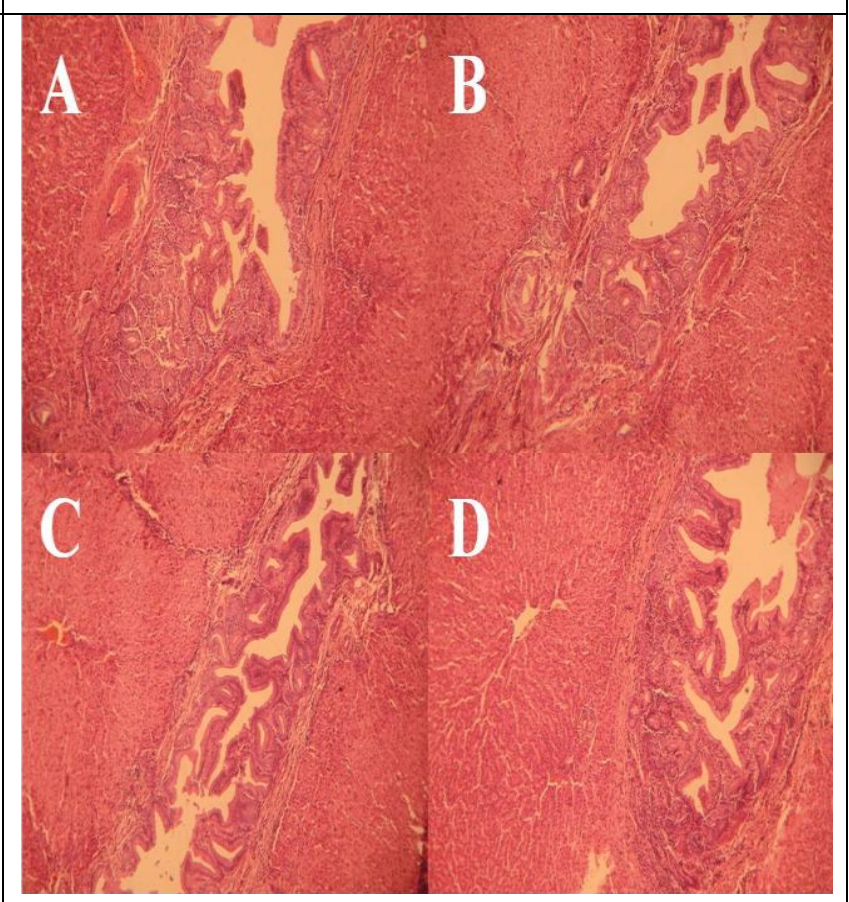

Fig.17 Proliferative biliary hyperplasia in capripox infected sheep and goats. (A-D) Nonneoplastic adenomatous changes together with moderate fibroplasia and cellular infiltration. All sections stained with H\&E, 100X. 


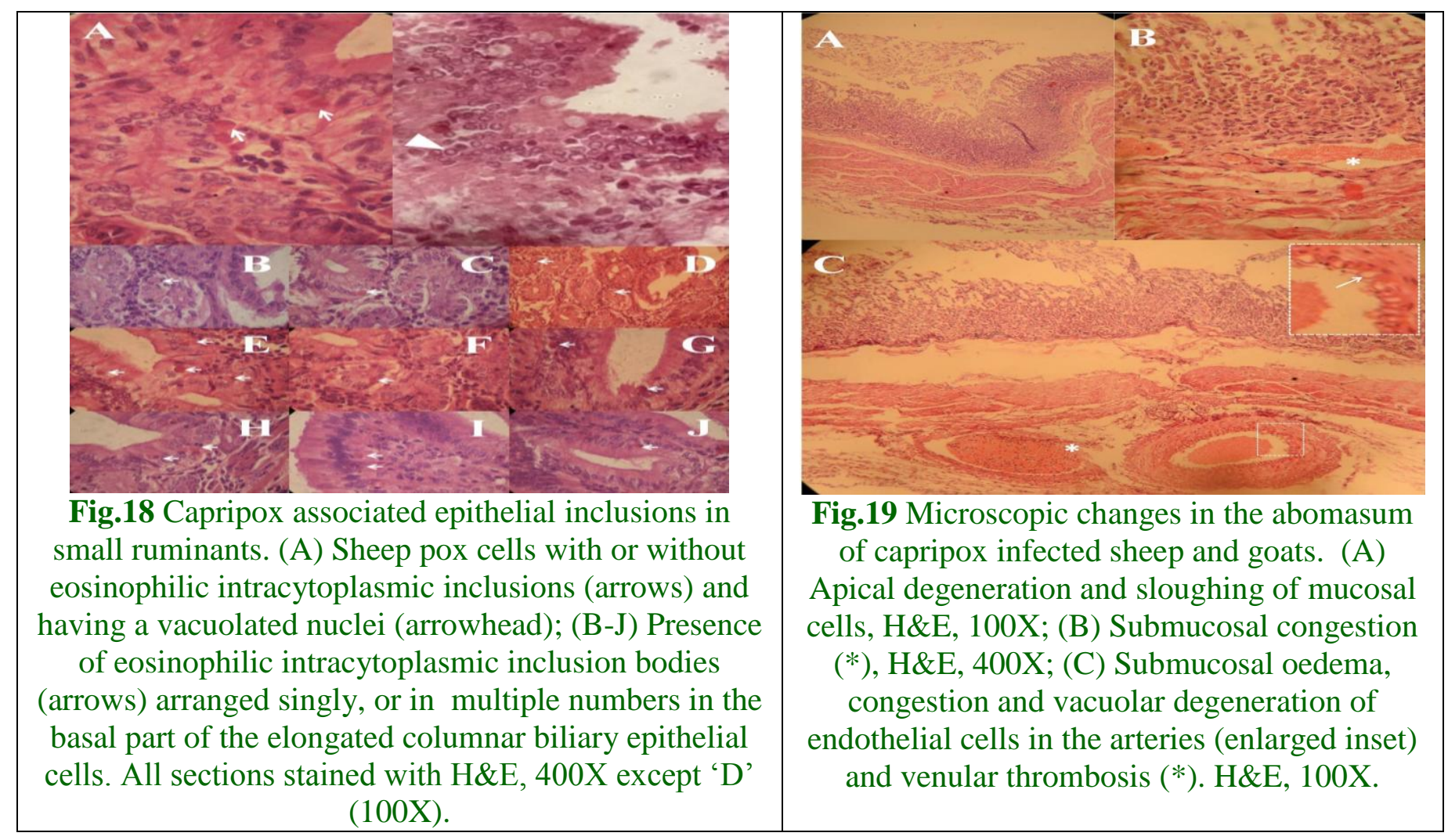

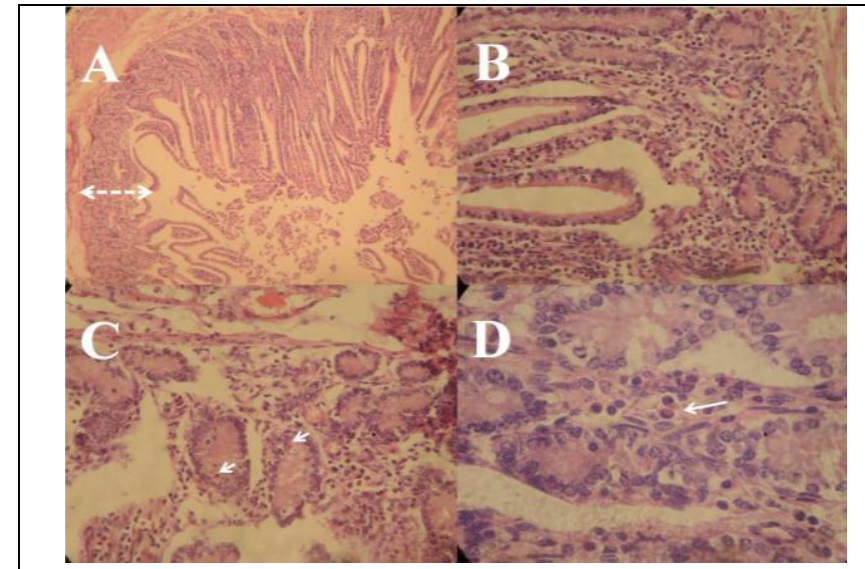

Fig.20 Microscopic lesions in intestine capripox infected sheep and goats. (A) Villous atrophy (double headed arrow), H\&E, 100X; (B) Infiltration of mononuclear cells in the lamina propria of the intestinal villi. H\&E, 400X; (C) Presence of eosinophilic cytoplasmic inclusions (arrows) within intestinal glandular epithelial cells. H\&E, 100X. (D) Eosinophils in the intestinal mucosa. H\&E, 1000X.

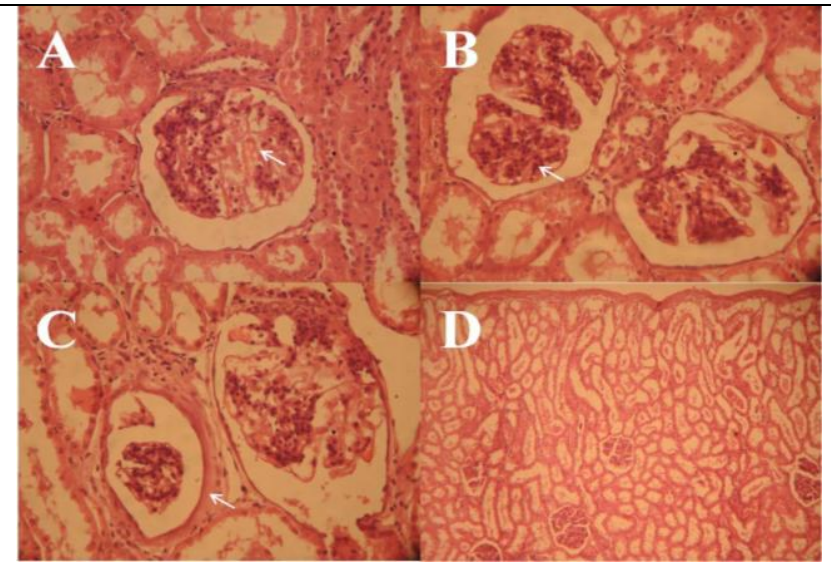

Fig.21 Microscopic lesions in the kidney of capripox infected sheep and goats. (A) Glomerulus show acute focal degenerative changes with loss of visceral epithelial cells, congestion and dilatation of capillaries. H\&E, 400X; (B) Proliferation of mesangial cells. H\&E, 400X; (C) Glomerular basement membrane appears thickened and duplicated with atrophy of glomerulus. H\&E, 400X; (D) Cortical tubular epithelium show degenerative changes, dilatation and accumulation of proteinaceous materials in their lumen. H\&E, 100X. 


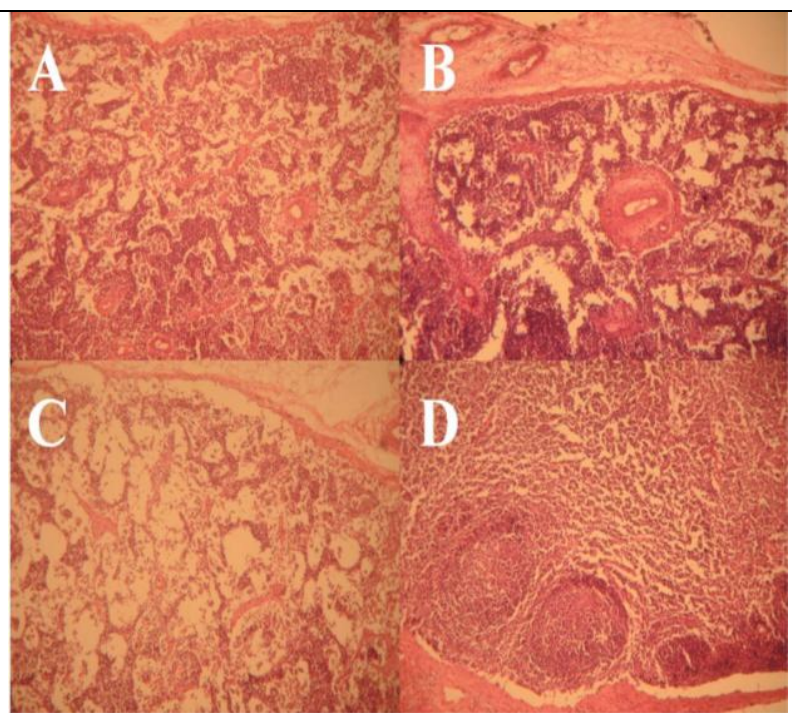

Fig.22 Lymphoid lesions in capripox infection in sheep and goats. (A) Lymphoid depletion and cystic cavitation in spleen of sheep. H\&E, 100X; (B) Lymphoid depletion and cystic cavitation in spleen of goat. H\&E, 100X; (C) Lymphoid depletion in cortical and paracortical areas of bronchial lymph node in sheep. H\&E, 100X; (D) Reactive germinal center and hyperplasia in bronchial lymph node in a goat. $\mathrm{H} \& \mathrm{E}, 100 \mathrm{X}$

However, previous observations of sheep pox cells in the kidneys of sheep by some workers (Vegad and Katiyar, 1998; Jubb et al., 2007; McGavin and Zachary, 2007) were not evident in any sections. Lymphoid depletion, decrease in the size and number of follicles, absence of germinal centers were some of the characteristic lesions observed in the present study that were corroborated by the findings of Manjunatha Reddy et al., (2015) and Aswini (2015). The subcapsular follicles in the spleen and the paracortical follicles in the bronchial lymph nodes were consistently affected, often leaving cystic cavitations. These observations tally with the earlier reports of Buller and Palumbo (1991), Saha et al., (1991) and Embury-Hyatt et al., (2012). Reactive and hyperplastic germinal centers observed presently in the bronchial lymph node of one goat conformed to the description of Sajid et al., (2012) in goats.

\section{References}

Abd-Elfatah, E.B., El-Mekkawi, M.F., Bastawecy, I.M., and Fawzi, E.M. (2018). Identification and phylogentic analysis of sheep pox during an outbreak of sheep in Sharkia Governorate, Egypt. Genetics and Molecular Research, 17: 2.

Abdel-Ghaffar, K.H.S. and Hassanein, K.M.A. (2009). Pathological study of malignant form of sheep pox. $10^{\text {th }}$ Scientific Congress of Cattle Disease, Faculty of Veterinary Medicine, Assiut University.

Achour, H.A., Bonguedour, R., Bouhbal, A., Guechtouli, A. (2000). Comparative study of immunizing ability of some attenuated strains of Sheeppox virus and sensitizing vaccine. Scientific and Technical Review of the Office International des Epizooties, 19(3): 773-783.

Afshar, A., Bundza, A., Myers, D.J., Dulac, G.C. and Thomas, F.C. (1986). Sheep pox: Experimental studies with a West African isolate. Canadian Veterinary Journal, 27(8): 301-306.

Aswini, B.S. (2015). Pathological and molecular diagnosis of sheep pox. MVSc thesis submitted to Sri Venkateswara Veterinary University, Tirupati, Andhra Pradesh, India.

Babuik, S., Bowden, T.R., Parkyn, G., Dalman, B., Hoa, D.M., Long, N.T., Vu. P.P., Bieu, D.X., Copps, J. and Boyle, D.B. (2009). Yemen and Vietnam capripoxviruses 
demonstrate a distinct host preference for goats compared with sheep. Journal of General Virolology, 90: 105-114.

Beard, P.M., Sugar, S., Bazarragchaa, E., Gerelmaa, U., Tserendorj, S.H., Tuppurainen, E., Sodnomdarjaa, R. (2010). A description of two outbreaks of capripoxvirus disease in Mongolia. Veterinary Microbiology, 142: 427-431.

Beytut, E. (2010). Sheep Pox Virus Induces Proliferation of Type II Pneumocytes in the Lungs. Journal of Comparative Pathology, 143: 132-141.

Bhanuprakash V, Venkatesan G, Balamurugan V, Hosamani M, Ogisharadhya R, Chauhan RS, Pande A, Mondal B, Singh RK. Pox outbreaks in Sheep and Goats at Makhdoom (Uttar Pradesh), India: Evidence of Sheep pox Virus Infection in goats. Transbound Emerg Dis. 2010; 57(5): 375-382.

Bhanuprakash, V., Indrani, B.K., Hosamani, M. and Singh, R. K. (2006). The current status of sheep pox disease. Comparative Immunology, Microbiology and Infectious Disease, 29: 2760.

Bhowmick, M.K., Ghosh, R.K., Bhattacharya, B. and Chakraborty, A.K. (1986). Goatpox in West Bengal. Indian Journal of Animal Health, 25: 15-18.

Bowden, T.R., Babiuk, S.L., Parkyn, G.R., Copps, J.S. and Boyle, D.B. (2008). Capripoxvirus tissue tropism and shedding: A quantitative study in experimentally infected sheep and goats. Virology, 371: 380-393.

Buller RM, Arif BM, Black DN, Dumbell KR, Esposito JJ, Lefkowitz EJ, McFadden G, Moss B, Mercer AA, Moyer RW, Skinner MA, Tripathy DN. Family Poxviridae. In Virus Taxonomy: Eighth Report of the International Committee on Taxonomy of Viruses, 117-133. Edited by Fauquet, C.M., Mayo, M.A., Maniloff, J., Desselberger, U., Ball, L.A., San. Diego: Elsevier Academic Press; 2005.

Buller, R. and Palumbo, G.J. (1991). Poxvirus pathogenesis. Microbiological Reviews, 55: 80-122.

Chanie, M. (2011). Clinical and Histopathological Study of Sheep Pox in Ethiopia. International Journal of Natural Sciences, 1(4): 89-92.

Daoud, J.A. (1997). Sheep in Jordan. Tropical
Animal Health and Production, 29(4): 251252.

Dar, L.M., Darzi, M.M., Mir, M.S., Kamil, S.A., Rashid, A., Abdullah, S., Hussain, S.A. and Bhat, A.A. (2012). Sheep pox virus induced interstitial pneumonia in sheep. International Journal of Livestock Research, 2(2): 159164.

Davies, F.G. (1976). Characteristics of a virus causing a pox disease in sheep and goats in Kenya, with observations on the epidemiology and control. Journal of Hygiene, Cambridge University, 76: 163-171.

Davies, F.G. and Otema, C. (1981). Relationships of Capripoxviruses found in Kenya with two Middle Eastern strains and some Orthopoxviruses. Research in Veterinary Science, 31 (2): 253-255.

Dutta, T.K., Sentil Kumar, V.S., Raina, A.K., Singh, R. and Wazir, V.S. (2002). An outbreak of sheep pox disease in an organized farm of Jammu and Kashmir. Indian Journal of Comparative Microbiology, Immunology and Infectious diseases, 23(2): 183-184.

El-Sabagh, I., Al-Shabebi, A., Abu-Elzein, E., Zaghawa, A., Al-Naeem, A., Housawi, F. (2014). Molecular detection and phylogenetic analysis of sheep pox virus in Al-Hassa of Eastern Province of Saudi Arabia. Advances in Animal and Veterinary Sciences, 2(2): 3134.

Embury-Hyatt, C., Babiuk, S., Manning, L., Ganske, S., Bowden, T.R., Boyle, D.B and Copps, J. (2012). Pathology and viral antigen distribution following experimental infection of sheep and goats with Capripoxvirus. Journal of Comparative Pathology, 146: 106115.

Ginn, P.E., Mansell, J.E.K.L. and Rakich, P.M. (2007). Skin and Appendages. In: Jubb, Kennedy, and Palmer's Pathology of Domestic Animals, Volume 1. Fifth edition. Maxie, M.G. (editor). Elsevier Saunders. Pp. 671-672.

Gitao, C.G., Mbindyo, $\quad$ C., Omani, R. and Chemweno, V. (2017). Review of sheep pox disease in sheep. Journal of Veterinary Medicine and Research, 4(1): 1068.

Govindarajan, R., Pazhanivel, N., Sundar, N., Sekar, M., Jawahar, T. and purushothaman, 
V. (2005). An outbreak of concurrent infection of theilleriosis and sheep pox in Tamil Nadu, India. Indian Journal of Animal Sciences, 75(7): 787-788.

Gulbahar, M.Y., Cabalar, M., Gul, Y. and Icen, H. (2000). Immunohistochemical detection of antigen in lamb tissues naturally infected with sheeppox virus. Journal of Veterinary Medicine Series B, 47: 173-181.

Gulbahar, M.Y., Davis, W.C., Yuksel, H. and Cabalar, M. (2006). Immunohistochemical evaluation of inflammatory infiltrate in the skin and lung of lambs naturally infected with sheep pox virus. Veterinary Pathology, 43: 67-75.

Guofu, C., Li, H., Zhou, S.I., Changqin, G. and $\mathrm{Hu}, \quad \mathrm{X}$. (2004). Pathomorphological Observation of Goat infected naturally with goat pox virus. Journal of Huazhong Agricultural University, 23(5): 543-546.

Hailat, N., Al-Rawashdeh, O., Lafi, S. and AlBateineh, Z. (1994). An outbreak of sheep pox associated with unusual winter conditions in Jordan. Tropical Animal Health and Production, 26: 79-80.

Haligur, M. and Ozmen, O. (2009). Immunohistochemical detection of matrix metalloproteinases (MMP) and Epidermal Growth Factor Receptor (EGFR) during sheep pox infection. Journal of Veterinary Medicine, 160(12): 574-581.

Hamouda, M., Al-Hizab, F., El-Sabagh, I. (2017). Clinical, pathological, and molecular diagnosis of Sheeppox virus in Saudi Arabia. The Journal of Animal and Plant Sciences, 27(1): 91-97.

Jayasri, K. (2015). Pathological and molecular diagnosis of goatpox. MVSc thesis submitted to Sri Venkateswara Veterinary University, Tirupati, Andhra Pradesh, India.

Jensen, R., Swift, B.L. and Kimberling, C.V. (1987). In: Jemsen and Swift's Diseases of Sheep, Lea and Febiger, Philadelphia, USA. $3^{\text {rd }}$ edition. Pp. 285-287.

Joshi, R.K., Ali, S.L., Shakya, S. and Rao, V.N. (1999). Clinico-Epidemiological studies on a natural outbreak of goat pox in Madhya Pradesh. Indian Veterinary Journal, 76: 279281.

Joshi, R.K., Chandra, R., Rao, V.D.P. and Garg, S.K. (1992). Goatpox: A review. Journal of
Applied Animal Research, 2: 57-72.

Jubb, K.V.F., Kennedy, P.C. and Palmer, N. (2007). Pathology of Domestic Animals, $5^{\text {th }}$ Edn, 2: 523-653.

Karapinar, Z., Ilhan, F., Dincer, E., Yıldırım, S. (2017). Pathology and phylogenetic analysis of capripoxvirus in naturally infected sheep sheeppox virus. Pakistan Veterinary Journal, 37(1): 78-84.

Kataria, A.K. and Sharma, K.N. (1992). A note on natural outbreak of sheep pox in Churu, (Rajasthan). Indian Journal of Animal Health, 31: 165.

Kitching, R.P. and Taylor, W.P. (1985). Clinical and antigenic relationship between isolates of sheep and goat pox viruses. Tropical Animal Health and Production, 17: 64-74.

Kumar, R. and Gupta, V.K. (2015). Pathological study of goat pox in a natural outbreak. Indian Veterinary Journal, 92(4): 70-71.

Luna, L.G. (1968). Manual of Histological Staining Methods of the Armed Forces Institute of Pathology, $3^{\text {rd }}$ Edn. McGraw Hill Book Co., New York.

MacLachlan, N.J. and Dubovi, E.J. (2011). In: Fenner's Veterinary Virology, $4^{\text {th }}$ edition. Academiv Press, Elsevier, Chennai, India.

Malik, Y., Chand, P. and Batra, S.K. (1998). Isolation and identification of a virus from a severe outbreak of pox in sheep. Indian Journal of Animal Sciences, 68(12): 12071209.

Manjunatha Reddy, G.B., Sumana, K., Babu, S., Yadav, J., Balamuragan, V., Hemadri, D., Patil, S.S., Suresh, K.P., Gajendragad, M.R. and Rahman, H. (2015). Pathological and molecular characterization of Capripox virus outbreak in sheep and goats in Karnataka. Indian Journal of Veterinary Pathology, 39(1): 11-14.

McGavin, M.D. and Zachary, J.F. (2007). Pathologic Basis of Veterinary Disease. $4^{\text {th }}$ Edn. Mosby Elsevier Westline Industrial Drive, St. Louis, Missouri, pp: 492-531.

Mohamed, K.A., Hago, B.E., Taylor, W.P., Nayil, A.A. and Abu-shmra, M.T. (1982). Goat pox in the Sudan. Tropical Animal Health Production, 14(2):104-108.

Mondal, B., Hosamani, M., Dutta, T.K., Sentilkumar, V.S., Rathore, R. and Singh, R.K. (2004). An outbreak of sheep pox in a 
sheep breeding farm in Jammu, India. Revue Scientifique et Technique de l'Office International des Epizooties, 23: 943-949.

Murray, M., Martin, W.B., Koylu, A. (1973) .Experimental sheep pox: a histological and ultrastructural study. Research in Veterinary Science, 15: 201-208.

Murthy, D.K. and Singh, P.P. (1971). Epidemiological studies on an outbreak of sheep-pox in a mixed flock in Uttar Pradesh. Indian Journal of Animal Sciences, 41(11): 1072-1079.

Nagapal, A.K., Vihan, V.S., Singh, S.V. and Singh, N.E.M. (1990). Epidemiological study of an outbreak of goat-pox and its effect on the performance of kids. Indain Journal of Animal Sciences, 60(5): 544 - 545.

Nashiruddullah, N. (2014). Molecular and Immunopathological Studies of Contagious Ecthyma (Orf) in Goats. PhD. Thesis submitted to Assam Agricultural University, Assam, India.

Nayak, B.C., Rao, A.T., Das, B.C. and Patnaik, R.K. (1984). Pathology of goatpox. Indian Journal of Animal Sciences, 54: 1012-1015.

OIE (2012). Sheeppox and goatpox. In: Terrestrial Manual Chapter 2.7.14.

OIE (2017). Sheep Pox and Goat Pox. In: Internationale des Epizooties (World Health Organization for Animals) Manual of Diagnostic Tests and Vaccines for Terrestrial Animals. 7:13: 1-12.

Ozmen, O., Kale, Haligur, M. and Yavru, S. (2009). Pathological, serological, and virological findings in sheep infected simultaneously with Bluetongue, Peste-despetitis-ruminants, and Sheep pox viruses. Tropical Animal Health Production, 41: 951958.

Pawaiya, R.V.S., Bhagwan, S.K. and Dubey, S.C. (2008). Histo-pathological study of goat pox in a natural outbreak. Indian Journal of Small Ruminants, 14(2): 266-270.

Raina, A.K., Singh, R., Dutta, T.K., Sentil Kumar, V.S. and Gupta, S.K. (2003). Epidemiological study of an outbreak of Sheep Pox Disease in an Organised Farm. Intas Polivet, 4(1): 72-75.

Ramakrishnan MA, Santhamani R, Pandey AB. Capripox outbreak in a mixed flock of sheep and goats in India. Transbound Emerg Dis.
2016; 64(1): 27-30.

Rana, R., Kumar, A. and Vihan, V.S (2005). Study of Goat Pox Outbreak and its Clinical Management. Indian Journal Animal Research, 39(2): 149-150.

Rashid, M., Sudhan, N.A. and Azmi, S. (2002). An outbreak of goat pox. Intas Polivet, 3(1): 112-113.

Roy, P., Purushothaman, V., Sreekumar, C., Tamizharasan, S., Andrew, Chandramohan. (2008). Sheep pox disease outbreaks in Madras Red and Mechery breeds of indigenous sheep in Tamilnadu, India. Research in Veterinary Science, 85: 617-621.

Sadhukhan, T., Nag, N.C., Basak, D.K., Biswas, A. and Das, R. (1999). Pathology of goat pox virus isolated from spontaneous disease. Indian Journal of Animal health, 38(2): 177.

Saha, G.R., Nayak, N.C. and Bhowmik, M.K. (1991). Studies on lymphoid lesions of goat pox. Indian Journal of Animal Research, 25: $1-4$.

Saha, G.R., Roy, S.S., Mukherjee, N. and Mitra, K. (1985). Clinical and epidemiological features of pox in black Bengal goats of west Bengal (India). Indian Journal of Animal Health, 24(1): 29-34.

Sajid, A., Chaudhary, Z.I., Sadique, U., Maqbol, A., Anjum, A.A., Muhammad, Qureshi, S., Hassan, Z.U., Idress, M. and Shahid, M. (2012). Prevalence of Goat Pox Disease in Punjab Province of Pakistan. The Journal of Animal and Plant Science, 22(2): 28-32.

Sharawi, S.S.A., Al-hofufy, A.N. and AI-habib, M.A. (2011). Comparison of Isolation and Conventional and developed indoor new SYBR GREEN REAL-TIME PCR assay for diagnosis of Sheep/Goat Pox and Contagious Ecthyma Viruses. Alexandria Journal of Veterinary Science, 33(1): 73-85.

Sharma, M.M., Uppal, P.K., Lonkar, P.S. and Mathur, P.B. (1986). Epidemiological study of a sheep pox outbreak in mutton and fine wool type sheep at an organized farm. Indian Journal of Animal Sciences, 56(12): 11831186.

Sharma, R., Patil, R.D., Parimoo, H.A., Thakur, D. and Katoch, V. C. (2013). ClinicoPathology of Sheep Pox Disease in Himachal Pradesh, India. Ruminant Science, 2(2): 127-130. 
Sharma, S., Hosamani, M., Singh, R.K., Kumar, H., Verma, S., Pan, D., Meenakshi, and Mahajan, V. (2008). PCR based confirmation of outbreaks of sheep pox. Indian veterinary Journal, 85: 1163-1165.

Singh, I.P., Pandey, R., Srivastava, R.N. (1979). Sheep pox: A review. Veterinary Bulletin, 49(3): 145-154.

Singh, R., Chandra, D., Singh, K.P., Hosamani, M., Singh, R.K. and Chauhan, R.S. (2007). Epidemiological investigation of sheep pox outbreaks in Rajasthan, India. Indian Journal of Veterinary Pathology, 31: 712-715.

Stein, R.A. and Staros, J.V. (2000). Evolutionary analysis of the ErbB receptor and ligand families. Journal of Molecular Evolution, 50: 397-412.

Tarello, W. and Kinne, J. (2007). Complete remission after treatment of Capripoxvirus infection in sheep using potassium arsenite $0.5 \%$ (Fowler's solution). Journal of Veterinary Medicine, 158(10): 489-492.

Tulman, E.R., Afonso, C.L., Lu, Z., Zsak, L., Sur, J.H., Sandybaev, N.T., Kerembekova, U.Z., Zaitsev, V.L., Kutish, G.F. and Rock, D.L. (2002). The genomes of sheep pox and goatpox viruses. Journal of Virology, 76(12): 6054-6061.

Tzahar, E., Moyer, J.D., Waterman, H., Bar-bacci, E.G., Levkowitz, G., et al., (1998). Pathogenic poxviruses reveal viral strategies to exploit the ErbB signaling net- work. EMBO Journal, 17: 5948-5963.

Vegad, J.L. and Katiyar, A.K. (1998). A Text book of Veterinary Systemic Pathology. Vikas publishing house.

Vegad, J.L. and Sharma, G.L. (1970). Pathogenesis of sheep pox virus in skin of experimentally infected sheep-macroscopic observation. Research Journal, 4: 32-36.

Verma, S., Verma, L.K., Gupta, V.K., Katoch,
V.C., Dogra, V., Pal, B. and Sharma, M. (2011). Emerging Capripoxvirus disease outbreak in Himachal Pradesh, a northern state of India. Transboundary and Emerging Diseases, 58: 79-85.

Wei-Liu, J., Hai-Tang, Z., Fei, W., Jun-Jie, C. and SI- Hong, Y. (2010). Clinical diagnosis technique of goat pox diseases. Agricultural Science and Technology, 11(7): 91-9.

Yager, J.A., Scott, D.W. (1985). The skin and appendages. In: Pathology of Domestic Animals, $3^{\text {rd }}$ Edit., Vol. 1, KVF Jubb, P.C., Kennedy, N. and Palmer, Eds., Academic Press, San Diego, pp. 408-526.

Yeruham, I., Yadin, H., Van Ham, M., Bumbarov, V., Soham, A., Perl, S. (2007). Economic and epidemiological aspects of an outbreak of sheep pox in a dairy sheep flock. Veterinary Record, 160: 236-237.

Zachary, J.F. and McGavin, M.D. (2012). Pathologic Basis of Veterinary Diseases, $5^{\text {th }}$ Edn. Mosby Elsevier Westline Industrial Drive, St. Louis, Missouri, pp.1022-1023.

Zangana, I.K. and Abdullah, M.A. (2013). Epidemiological Clinical and Histopathological Studies of lamb and kid pox in Duhok, Iraq. Bulgarian Journal of Veterinary Medicine, 16(2): 133-138.

Zhou, B.J., Juan, Y.U., Zhi, X.C., Tao, C.Z., Jun, Y. and Ming, W. (2007). Pathogenic identification and pathological observations of goat pox cases in Guizhou Province. Journal of Veterinary Science in China, 37: 525-528.

Zro, K., Zakham, F., Melloul, M., El Fahime, E. and Ennaji, M.M. (2014). A sheep pox outbreak in Morocco: isolation and identification of virus responsible for the new clinical form of disease. Bio Med Central Veterinary Research, 10: 31.

\section{How to cite this article:}

Sankalp Sharma, Nawab Nashiruddullah and Jafrin Ara Ahmed. 2020. Pathology of Spontaneous Pox Virus Infection of Sheep and Goat in Jammu Region. Int.J.Curr.Microbiol.App.Sci. 9(06): 1204-1226. doi: https://doi.org/10.20546/ijcmas.2020.906.150 